\title{
Analyzing the impact of environmental variables on the repayment time for solar farms under feed-in tariff
}

\author{
Bin $\mathrm{Lu}^{1 *}$ and Matt Davison ${ }^{2}$
}

\begin{abstract}
Background: Environmental concerns have promoted the rise of low emissions "green" power technologies such as solar power. In part to make these technologies of economic interest to investors, many green energy policies have been proposed, and a wide variety of green energy developments have been launched which take advantage of these policies. This paper studies the impact of the unpredictable solar insolation on two variables of key interest to solar plant developers: the repayment time and the cash flow at risk.
\end{abstract}

Results: Using a bootstrap analysis of solar irradiation time series, we model solar farms which sell their power output at a Feed-In Tariff (FIT) rate motivated by one used in the province of Ontario, Canada. We show that the feed-in tariff level which existed in Ontario in March 2012 was more than sufficient to remove the financial risks inherent in financing a solar PV plant.

Conclusions: We conclude that the Ontario Canada FIT 2012 program was an effective tool to encourage investment in solar PV plants. We also find that repayment time is strongly sensitive to FIT rates. So FIT is a very efficient tool to impact/control the volume risk.

Keywords: Solar PV, Feed-In Tariff, Repayment time, Bootstrap

\section{Background}

The renewable energy market has seen rapid growth during the past few years. According to the Renewables 2010 Global Status Report (REN21 2010), investment in clean energy assets (not including large hydro) was $\$ 29.5$ billion in the first quarter of 2010,63\% above that in the same period of 2009. The global capacity of many renewable technologies increased at rates of $10-60 \%$ annually during the period from the end of 2004 through 2009. In the power sector, though conventional fuels (fossil fuels and nuclear) remain the primary suppliers of global energy, power production from renewable energy (excluding large hydro) increased by $22 \%$ in 2009 . Worldwide among all types of renewable power generating technologies, solar photovoltaic (PV) power continues to be the fastest growing power generation technology. Cumulative global PV

\footnotetext{
*Correspondence: blu7@uwo.ca

1 Department of Applied Mathematics, University of Western Ontario, London, ON N6A 5B7, Canada

Full list of author information is available at the end of the article
}

installed capacity was almost six times larger in 2012 than in 2004 (REN21 2010). In 2009, about 16\% of all new electric power capacity additions in Europe were credited to Solar PV (REN21 2010). In North America, an estimated $470 \mathrm{MW}$ of solar PV was installed in 2009 in the United States (REN21 2010) where $1800 \mathrm{MW}$ of PV is expected to be installed on the power grid by 2013. Over $1600 \mathrm{MW}$ of PV was under development in Ontario, Canada at the end of 2011 (Ontario Power Authority 2011).

Some facts of solar PV power are particularly favorable for investors: 1) The source of solar photo-voltaic (PV) is free and clean; 2) Solar PV power is easier to predict and more reliable/stable than wind power. Sunlight levels, while still at the mercy of weather patterns, are not as unpredictable as wind speeds; the fact that solar cells don't work at night is at least a predictable feature of their design; 3) Research (Rowlands 2005; Perez et al. 2012) conducted in the United States and Canadian electricity markets finds that solar PV power is highly associated with peak market demand and to somewhat lesser extent associated with high power prices. It also points out that

\section{算 Springer}

(c) 2013 Lu and Davison; licensee Springer. This is an Open Access article distributed under the terms of the Creative Commons Attribution License (http://creativecommons.org/licenses/by/2.0), which permits unrestricted use, distribution, and reproduction in any medium, provided the original work is properly cited. 
the PV power is a potential solution to provide dependable peak power to meet growing summertime demand. However, investors must balance these desirable features against the high capital cost of solar PV power. Although a great deal of analysis has been done on the scientific and engineering development of solar cells, much less literature exists on the economic analysis of these cells. The paper by (Powell et al. 2009) calculates various financial indicators for an "organic" solar cell. Their work uses an approach (complementary to the one taken here) for simulating ground level insolation measurements for which historical data does not exist. The repayment time metric is calculated in the (Powell et al. 2009) paper, but assuming market electricity prices, and finds that payback periods are too large to be economically viable. In a later work, (Azzopardi et al. 2011) compute the average cost of generated power metric for such organic solar cells.

The dramatic growth in the solar PV industry has come in large part because of substantial government support. In the first decade of the 21st century, the world's major governments launched, updated or modified several programs to ensure that financial and administrative instruments are available to aid the development of renewable energy. Common policy measures for promoting solar PV power generation are feed-in tariffs, capital subsidies or grants, tax credits, net metering and direct public investment or financing. The most common policy used to encourage solar PV power is the feed-in tariff (FIT). A FIT offers stable prices under long-term contracts for energy generated from renewable sources. Germany is a pioneer and advocate for feed-in tariff policy among European countries. In 2000, Germany adopted the Renewable Energy Sources Act (Germany 2000), which is a replacement of the previous Electricity Feed Act launched in the 1990's. The German Renewable Energy Sources Act turned out to be a great success and has since been amended several times. Following Germany's success, between 2005 and 2010 at least 50 countries and 25 states or provinces adopted feed-in tariffs (REN21 2010). For instance, France adopted a feed-in tariff of EUR 4258 cents $/ \mathrm{kWh}$ for ground-mounted PV systems in 2009 (REN21 2010). Japan also implemented its first feed-in tariff of JPY 48/kWh for residential PV systems in 2009 (REN21 2010). In the Province of Ontario Canada, the current (2012) FIT program provides much higher rates than the market price for the electricity generated from solar PV. In addition, the rates are fixed even though the market price is variable. The Ontario FIT offers CAD 44 cents/kWh for large scale solar PV plants (Ontario Power Authority 2012). On the other hand, the monthly volume weighted average Hourly Ontario Energy Price (HOEP) between 2003 and 2011 has always been below CAD 10 cents/kWh (IESO 2012).
An investor in solar PV projects faces high risks, of which the three largest are: high capital costs, price risk, and volume risk. As mentioned above, high capital cost is indeed a concern but the trend of such costs is falling and capital subsidies may be available in local jurisdictions. Price risk arising from highly volatile electricity prices is another big issue in power plant financing. Even though solar PV power, which is not generated during the low demand night time hours, is associated with peak electricity prices (Rowlands 2005), this does not suffice to remove all price risk. The goal of a FIT program is to provide constant power rates, thereby removing price risk, and to make these rates sufficiently large that sufficient funds may be generated by the developer even in years which are not very sunny, thereby vastly reducing the impact of volume risk. This paper presents a statistical framework for answering the question of whether a given feed-in tariff is high enough to effectively eliminate both price and volume risk. The statistical framework is applied to show that the FIT tariff level in 2012 Ontario sufficed to eliminate solar farm volume risk, as measured by two financial metrics.

Risks other than volume risk include weather damage to panels from hail or snow, faster than expected degradation in panel performance due to extreme cold or heat and transmission line failure. This paper does not consider these risks, which may be hedged using insurance or product warranties.

This paper presents a representative case study from the city of London in the Canadian province of Ontario. The case study demonstrates how FIT performs as a financial inducement to promote solar PV power generation. We seek to answer the question: is the Ontario FIT price at the correct level? This question is answered using two types of financial metric. The first is based on the repayment time. This is the length of time a developer would take to repay the loan taken out to construct the solar farm. This repayment time will fluctuate according to future sunshine level patterns, and so will be a random variable; histograms of the outcomes of this random variable will be generated and reported. The repayment time conclusions are then reinforced using calculations of the Cash Flow at Risk (CFaR) metric (RiskMetrics Group 1999). The relatively new CFaR metric captures some of the risks due to uncertain cash flows in a way that is impossible for a more traditional engineering economic analysis performed using a Discounted Cash Flow approach (White et al. 2010). The CFaR metric reports the worst cash flow that can happen at a given materiality threshold; for instance, that 19 times out 20 the worst lowest cash flow that would be realized in a given year is X. Minimal work has focused on the application of the $\mathrm{CFaR}$ metric in the solar PV industry; this new metric will introduce an important new perspective for solar investors. The results 
of the repayment time and CFaR studies both show that the Ontario FIT levels were, in 2012, more than sufficient to cover the variable insolation risk considered here.

The rest of this paper is organized as follows. Section 'Solar PV financial basics' describes the financial basics of a solar PV plant. Section 'Impact of volume risk on repayment time' describes the methodology used to analyze repayment time of a solar PV plant and discusses the results. Section 'Sensitivity analysis' presents a sensitivity analysis. Section 'Cash flow at risk' presents a Cash Flow at Risk analysis. Section 'Conclusions' concludes the paper.

\section{Solar PV financial basics}

Solar energy comes from incoming solar radiation (insolation). A solar PV plant employs solar panels to directly convert sunlight into electricity. A solar PV power plant is characterized both by its geographical location and by its installed capacity. Installed capacity, also known as nominal capacity or nameplate capacity, refers to intended sustained power output levels under ideal conditions. The ideal working condition for a PV array is at a cell temperature of $25^{\circ} \mathrm{C}$ and at solar irradiance of $1000 \mathrm{~W} / \mathrm{m}^{2}$. This is called the standard test condition (STC) of a solar cell. However, PV arrays rarely operate under these conditions. The actual output of the plant varies with orientation and efficiency of PV arrays, time of the day, season of the year and state of the atmosphere. The capacity factor is a measurement of the efficiency of the plant's actual output power. Solar PV capacity factors are typically under $25 \%$ (Bellemare 2003).

\section{DCF analysis}

It is common in engineering economic analysis (White et al. 2010) to employ discounted cash flow calculations. This methodology is also known as net present value (NPV) analysis. Future net cash receipts of a project are projected and then discounted with the appropriate time value of money and then summed to decide if a project is worthwhile. Within the DCF framework, the repayment time is a common metric to characterize the economic performance of industrial projects. Some papers (Drury et al. 2011; Sidira and Koukios 2005) use time-to-netpositive-cash-flow (TNP) payback time which is similar to the repayment time idea used in this paper. The repayment time is the earliest time at which a project is able to repay all of its debt. In other words, for our example, it is the time horizon for which the solar PV plant has zero net present value. NPV or DCF analyses are standard ways to evaluate investment profitability. For example, both (Drury et al. 2011; Pappas et al. 2012; Rehman et al. 2007; Borenstein 2008) used NPV as an indicator in their economic analysis.

The cash outflow in a solar PV plant contains initial investment (the cost of purchasing and installing solar modules, land cost etc.) as well as annual operation and maintenance $(\mathrm{O} \& \mathrm{M})$ costs. The annual cash inflow of a solar PV plant is simply the sales resulting from selling the electricity the panels generate from solar irradiation. Negative numbers denote cash outflows and positive numbers denote cash inflows. All annual inflows are discounted back to a common initial reference time $t_{0}$ using a common discount rate or internal rate of return. The first time at which the present value of all cash outflows exactly balances the present value of all cash inflows is termed the repayment time of the plant. In mathematical terms the result is equation (1).

$$
V(t)=-C_{0}-\sum_{i=1}^{t} \frac{O M_{i}}{\left(1+r_{O M}\right)^{i}}-\sum_{i=0}^{t-1} \frac{L_{i}}{\left(1+r_{L}\right)^{i}}+\sum_{i=1}^{t} \frac{E_{i}}{\left(1+r_{E}\right)^{i}} .
$$

Here:

$V(t)$ is the present value of solar PV plant [Units \$], $C_{0}$ is the initial capital cost [Units $\$$ ], $t$ is the time, measured in years [Units years], $O M_{i}$ denotes the O\&M costs for $i$ th year [Units $\$$ ] [N.B. paid in arrears, see section 'Land cost'], $L_{i}$ denotes the land costs for $i$ th year [Units $\$$ ] [N.B. paid in advance, see section 'Land cost'], $r_{O M}$ is the real interest rate for OM cost [Units $\% /$ year],

$r_{L}$ is the real interest rate for land cost [Units \%/year], $r_{E}$ is the real interest rate for energy price [Units $\% /$ year], $E_{i}$ denotes the earnings for $i$ th year by selling electricity [Units $\$$ ].

\section{Parameter identification \\ Solar PV plant}

Our case study assumes a PV plant of capacity $10 \mathrm{MW}$ is to be built in a rural area near London Ontario, Canada. We assume that the power plant will operate for 20 years in order to match the terms of Ontario's FIT contract. We assume the PV plant capacity factor to be $16 \%$ and that inverters of the PV system which convert direct current (DC) to alternating current (AC) are 90\% efficient. To install a nominal capacity of $1 \mathrm{~kW}$ modules, an area between $7 m^{2}$ and $10 m^{2}$ is required (Solar Server 2010). This plant requires an area of approximately $70,000 \mathrm{~m}^{2}$ (approximately equivalent to 17.29 acres) for a solar PV plant with $10 \mathrm{MW}$ installed capacity.

\section{Interest rates}

We assume that the project is financed before construction and that the same interest rate applies for all cash flows. To estimate the applicable rate, we consider Clean Renewable Energy Bonds (CREBs), a federal loan program sponsored by US Internal Revenue Service (IRS) to finance eligible clean renewable energy projects. On March 1st 
2012, the interest rate of a CREB with 20-year maturity was $4.79 \%$ (U.S. Treasury 2012). Therefore we believe it is appropriate to estimate an interest rate of $5 \%$ for our case study.

\section{Module cost}

Generally, PV module costs represent $40-60 \%$ of total PV system costs, and installation costs account for the remaining costs (REN21 2010). The larger the solar plant, the smaller the installation cost for each unit.

As of 2007, the unit installation cost for a typical 10kW residential system was $\$ 8.00 / W$ (Borenstein 2008).

By the end of 2009, solar PV module prices fell below $\$ 2.00 / W$ in some instances (REN21 2010). If we double that to include installation costs, we may assume a total cost of $\$ 4.00 / W$ for solar PV systems module and installation.

Combining the above information with the figures quoted in (International Energy Agency 2009) and (Drury et al. 2011), where average annual PV system costs was reported as $\$ 3.85 / W$ and $\$ 3.91 / W$ respectively, we believe it is reasonable to assume the costs of PV modules and installation are $\$ 4.00 / W$ in this case study.

Typical OM costs are $1 \%$ of total initial investment (PVResources 2012).

\section{Land cost}

One may purchase or rent the premise in order to run the power plant. In this case study, we assume the solar farm operator leases a premise in rural area. The land so rented is assumed to be otherwise unproductive except for relatively low value agricultural or recreational uses. According to a survey in (Weersink et al. 2011), the weighted average monthly rent for Middlesex County (which surrounds London, Ontario) was \$200/acre in summer 2010. Therefore, we estimate a total land rent of $\$ 3,458 /$ month. In Ontario, rent is typically paid in advance. The details of a lease will vary across rental agreements, but to be conservative we assume that the rent is paid one year in advance. In contrast, work done is often paid in response to the receipt of an invoice, which must be settled on normal business terms of for example 90 days in arrears, so it makes sense to model other costs of the project as being covered at the end of the year. The interest rates used in this analysis are low enough to make the impact of these choices rather small in the final results.

\section{Insolation}

We obtained hourly global insolation from 1955 to 2004 at London International Airport weather station from Environment Canada Canadian Weather Energy and Engineering Data Sets (CWEEDS) (Environment Canada 2012). our financial model requires annual cash flows, so we average the data set by year in order to get a constant daily global insolation for each year.

\section{Ontario's FIT}

The FIT in Ontario guarantees that all power generated from solar PV plants may be sold at $\$ 0.44 / k W h$ (Ontario Power Authority 2012).

\section{The calculation}

By listing all the details and calculations each year's cashflow from equation (1), we obtain the following tables for DCF analysis. These tables may then be used to compute various financial metrics including repayment time.

Tables 1 and 2 include all parameters and the DCF calculations. Table 1 exhibits the values for input parameters and steps for carrying out annual income (not yet discounted) from selling solar-generated power. Table 2 lists each year's cash flow after applying the appropriate discount factors.

\section{Methods}

Tables 1 and 2 serves the purpose of demonstrating the DCF analysis. We denote the result of Table 1 the "constant insolation" scenario since we use constant daily global insolation for each operating year in the above DCF analysis. But in reality, insolation is random, fluctuating around some constant level. As financing a solar PV plant involves a huge amount of capital, decision makers must thoroughly understand all risks which impact the plant's repayment time. As mentioned in section 'Introduction, volume risk is the major remaining risk. In order to reflect the impact of volume risk on the repayment time, we introduce some dynamics to model the solar insolation.

Although cloud cover data is readily available, it turns out to be unsuitable for the current purpose, for reasons explained in Appendix A.

The next step is to apply both retrospective and bootstrap analysis to model randomness of solar insolation. Some data abnormality issues emerge. The next subsection explains these abnormalities and then return to retrospective and bootstrap analysis.

\section{Data abnormality}

Our data is the CWEEDS hourly global insolation at London International Airport from 1955 to 2004. We average every year's hourly global insolation to obtain annual total global insolation. The time series for annual average global insolation are plotted in Figure 1, which reveals some possible data inconsistency issues.

If we determine the maximum reading for each individual hour from each year, we observe two regimes of data from some of these time series. For example, we pick the annual maximum irradiance for 11AM, noon (12PM), 
Table 1 DCF analysis input parameters, annual production etc

\begin{tabular}{|c|c|c|c|}
\hline & Quantity & Unit & Total \\
\hline \multicolumn{4}{|l|}{ INITIAL SYSTEM COST } \\
\hline Installed Capacity & 10 & MW & \\
\hline panel purchase and installation & 4 & $\$ / W$ & \\
\hline Initial System Cost Total & & $\$$ & $40,000,000$ \\
\hline \multicolumn{4}{|l|}{ OTHER COSTS } \\
\hline Land Area & 17.29 & acre & \\
\hline Land Rent & 200 & \$/acre/month & \\
\hline Land Cost Total & & $\$ / y r$ & 41,496 \\
\hline Application Cost & & $\$$ & 5,000 \\
\hline \multicolumn{4}{|l|}{ OM COSTS } \\
\hline$\%$ of Installation Costs & 1 & $\%$ & \\
\hline OM Annual Total & & $\$$ & 400,000 \\
\hline \multicolumn{4}{|l|}{ ANNUAL PRODUCTION } \\
\hline Installed Capacity & 10 & MW & \\
\hline Mean daily global insolation in Toronto Area & 4 & $\mathrm{kWh} / \mathrm{m}^{2}$ & \\
\hline Total Energy received annually & & $\mathrm{kWh} / \mathrm{m}^{2} / \mathrm{yr}$ & 1,394 \\
\hline PV moduel efficiency & 16 & $\%$ & \\
\hline Total Annual DC output & & $\mathrm{kWh} / \mathrm{m}^{2} / \mathrm{yr}$ & 251 \\
\hline $\mathrm{DC}$ to $\mathrm{AC}$ conversion factor & 90 & $\%$ & \\
\hline Estimated actual Annual output & & $\mathrm{kWh} / \mathrm{m}^{2} / \mathrm{yr}$ & 226 \\
\hline Area of modules needed to provide this rated capacity & 70,000 & $m^{2}$ & \\
\hline Estimated annual kilowatt hours & & $\mathrm{kWh} / \mathrm{yr}$ & $14,069,261$ \\
\hline Ontario FIT rates & 0.44 & $\$ / \mathrm{kWh}$ & \\
\hline Estimated Annual Income & & $\$ / y r$ & $6,232,683$ \\
\hline Annual Interest rate & 5.0 & $\%$ & \\
\hline
\end{tabular}

Table 2 DCF calculation of each year's revenues, costs and net profit, in 2012 Canadian dollars

\begin{tabular}{|c|c|c|c|c|c|}
\hline & Year 0 & Year 1 & Year 2 & Year 3 & Year 4 \\
\hline Initial System Cost & $(40,005,000)$ & & & & \\
\hline OM Cost & & $(380,952)$ & $(362,812)$ & $(345,535)$ & $(329,081)$ \\
\hline Land Cost & $(41,496)$ & $(39,520)$ & $(37,638)$ & $(35,846)$ & $(34,139)$ \\
\hline Electricity Sales & & $5,935,888$ & $5,653,227$ & $5,384,026$ & $5,127,643$ \\
\hline Cumulative Income & & $5,935,888$ & $11,589,115$ & $16,973,140$ & $22,100,784$ \\
\hline Cashflow & & $(34,450,064)$ & $(29,159,649)$ & $(24,121,159)$ & $(19,322,596)$ \\
\hline Year 5 & Year 6 & Year 7 & Year 8 & Year 9 & Year 10 \\
\hline$(313,410)$ & $(298,486)$ & $(284,273)$ & $(270,736)$ & $(257,844)$ & $(245,565)$ \\
\hline$(32,513)$ & $(30,965)$ & $(29,490)$ & $(28,086)$ & $(26,749)$ & $(25,475)$ \\
\hline $4,883,470$ & $4,650,924$ & $4,429,451$ & $4,218,525$ & $4,017,643$ & $3,826,326$ \\
\hline $26,984,254$ & $31,635,177$ & $36,064,628$ & $40,283,153$ & $44,300,796$ & $48,127,122$ \\
\hline$(14,752,537)$ & $(10,400,100)$ & $(6,254,921)$ & $(2,307,132)$ & $1,452,667$ & $5,033,428$ \\
\hline
\end{tabular}




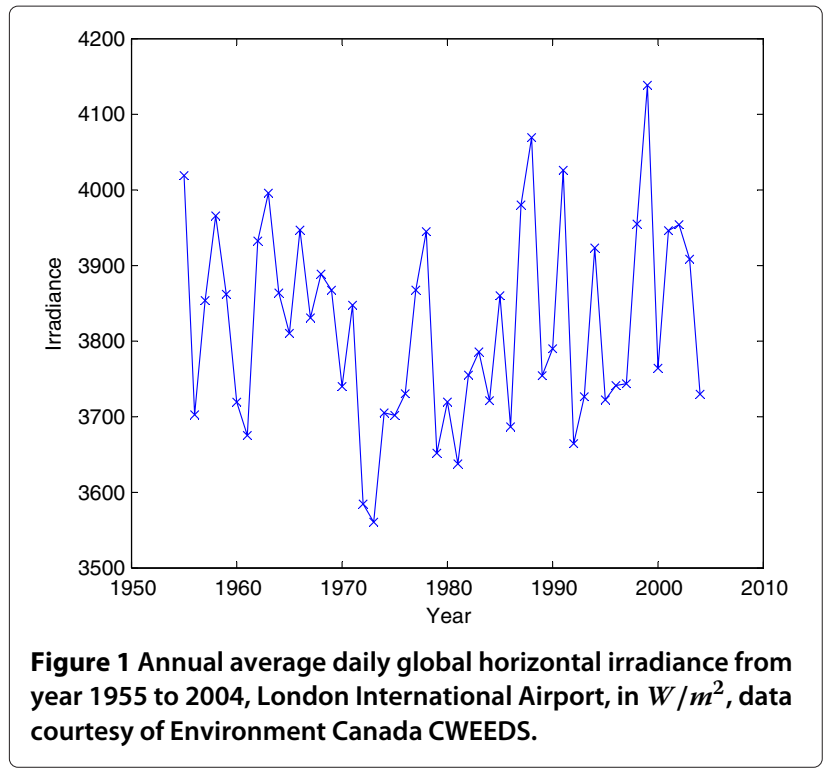

1PM and 2PM separately. The time series plots for those hours are shown in Figure 2.

There clearly appears to be two sets of data with different average levels in each of these plots. The difference of these two average levels is about $10 \%$. The reason for this is unknown although we suspect a change in measurement technique around 1978. Because of this issue, we choose to use only data from 1978 and after in order to remain consistent with measured recent data.

\section{Data autocorrelation}

Evidence fails to support the hypothesis that the total annual insolation at a point is meaningfully autocorrelated, although of course is likely autocorrelation at higher frequencies. The lack of annual autocorrelation is seen in the autocorrelation (acf) plot of Figure 3 which shows that the autocorrelations at all nonzero lags lie below the significance threshold which distinguishes them from zero. Further evidence is given by the related scatter plot of Figure 4 which plots insolation at year $k+1$ against insolation at year $\mathrm{k}$. The regression line fitted to the Figure 4 data shows little evidence of autoregressions even at time lag 1 .

\section{Retrospective and bootstrap analysis}

Now we are ready to employ retrospective and bootstrap analysis on the data sample. The retrospective and bootstrap analyses use identical settings to the constant insolation scenario, with the one change being that they model fluctuations in the annual global insolation. We no longer assume constant insolation. We specify the contract life to be 20 years. So each time we need to generate 20 random numbers to give the insolation for each year in order to work out the repayment time problem.

Retrospective analysis means evaluating what would have happened with actual historical results. We apply the actual observed sequence of historical insolation. Each sequence contains 20 observations. In other words, retrospective analysis shows the repayment time for a solar
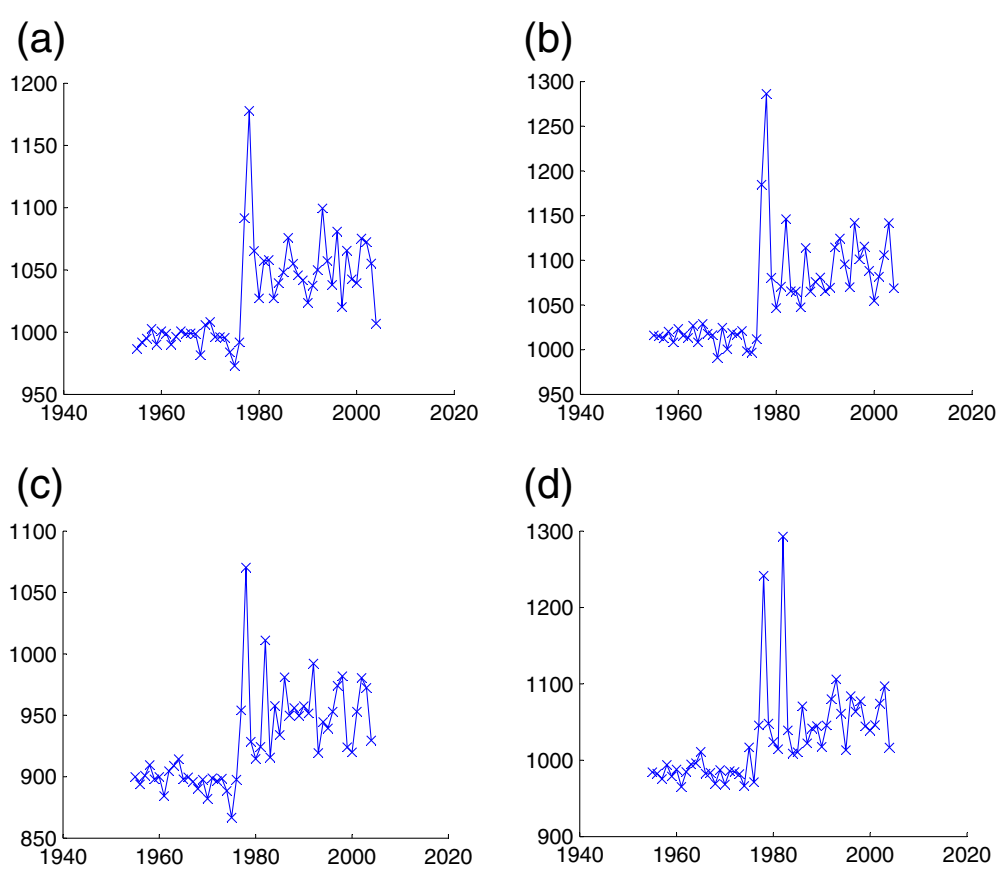

Figure 2 Annual maximum daily global horizontal irradiance at $11 \mathrm{am}, 12 \mathrm{pm}, 1 \mathrm{pm}$ and $2 \mathrm{pm}$ respectively, in $\mathrm{W} / \mathrm{m}^{2}, 1955-2004$, London International Airport, data courtesy of Environment Canada. 


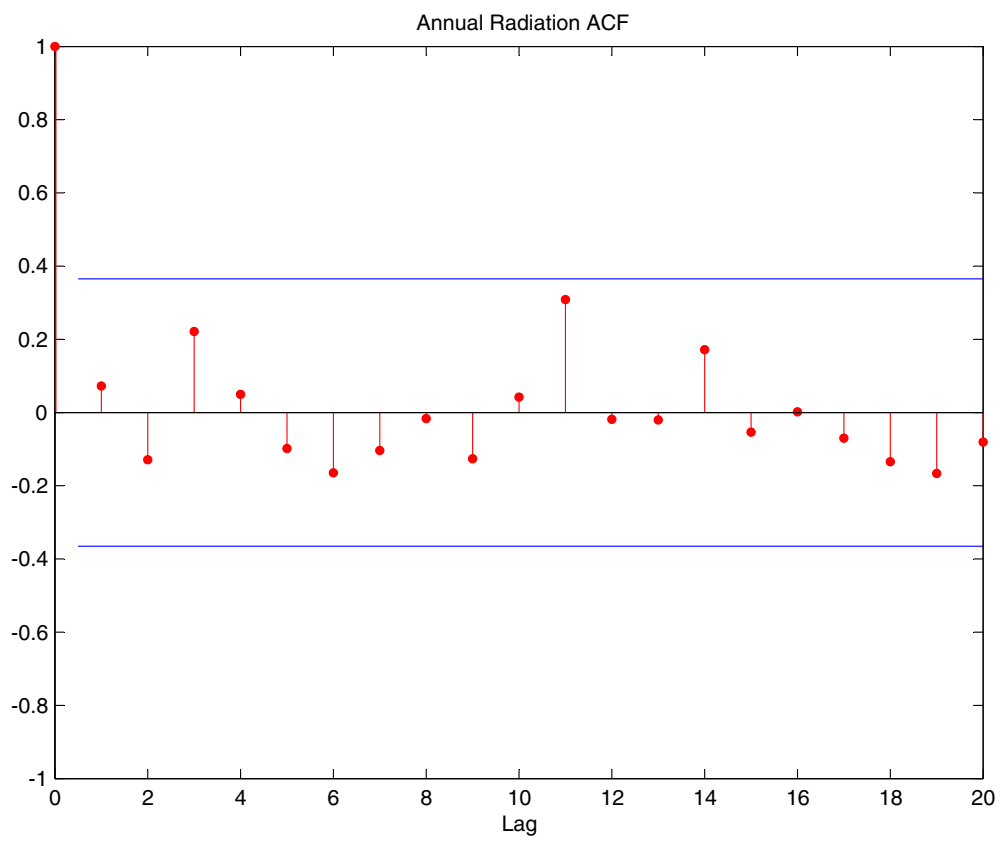

Figure 3 Autocorrelation vs. time lag. Annual insolation data at London international airport, Ontario 1975 - 2004. All points lie between the horizontal lines representing measured acf statistically indistinguishable from zero.

plant as if it were built in 1978, 1979 etc up to 1995. In this case, the sample size is small with only 8 samples in total, i.e. 1978-1997, 1979-1998 up to 1985-2004. Therefore we could work out the average repayment time under retrospective analysis.

It is impossible, given the constraints of limited data, to come up with 10,000 completely different retrospective results. In order to model more variability in solar insolation, we use the bootstrap method (Efron and Tibshirani 1994). The bootstrap is a statistical technique

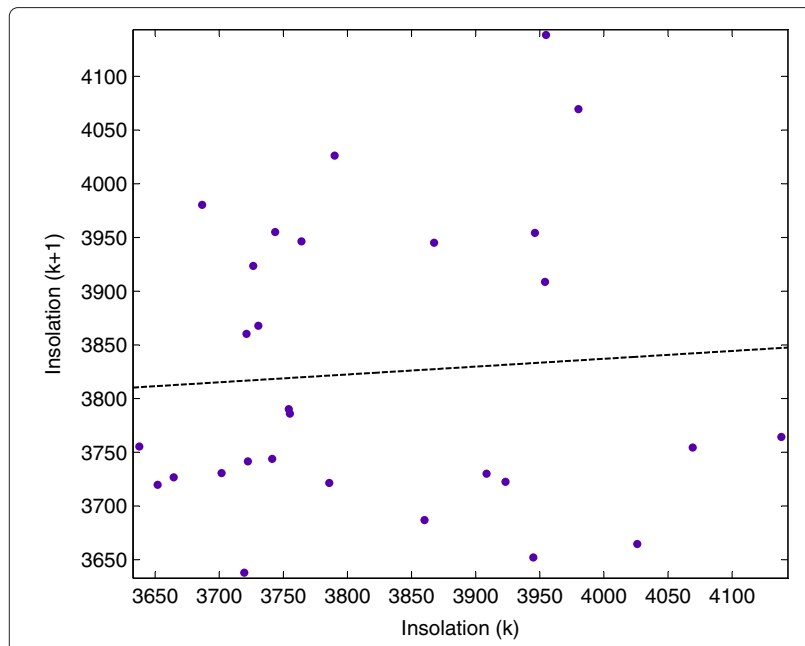

Figure 4 Insolation year (k) vs. Insolation year $(k+1)$ from 1975 to 2004. The line of best fit through the data is $y=0.07294 x+3545$ with $R^{2}=0.005384$ that strongly depends on the development of computer technology. It is extremely useful when the underlying distribution is complicated or unknown or when sample data is insufficient.

Each time, we sample with replacement from the historical annual global insolation data pool to generate a new sequence of annual insolation. We call this sequence of data a sample path. By generating $\mathrm{N}$ sample paths (in our simulation, $\mathrm{N}=10,000$ ), we are able to estimate the distribution of the repayment time. $\mathrm{N}$ will be chosen sufficiently large to estimate financial metrics within our desired accuracy levels. Retrospective analysis may be considered a very special case of bootstrapping in which just the sample paths which actually occurred are used.

\section{Results and discussion}

The bootstrap technique described in section 'Retrospective and bootstrap analysis' is used to generate 10,000 possible total annual insolation sequences. Using the economic model for the solar plant described in Section 'Solar PV financial basics', the time required to repay the capital costs of the plant is calculated on each of these sequences. A histogram of the resulting fraction of runs leading to a given repayment time interval is provided in Figure 5.

Figure 5 is a bell shaped curve with a slightly heavy right tail. The peak value of repayment time lies between 9.50 and 9.60 years. The average repayment time by bootstrap analysis is 9.49 years and 9.45 by retrospective analysis.

Note that the repayment time reported by (Powell et al. 2009) is about twice that reported here. This makes 


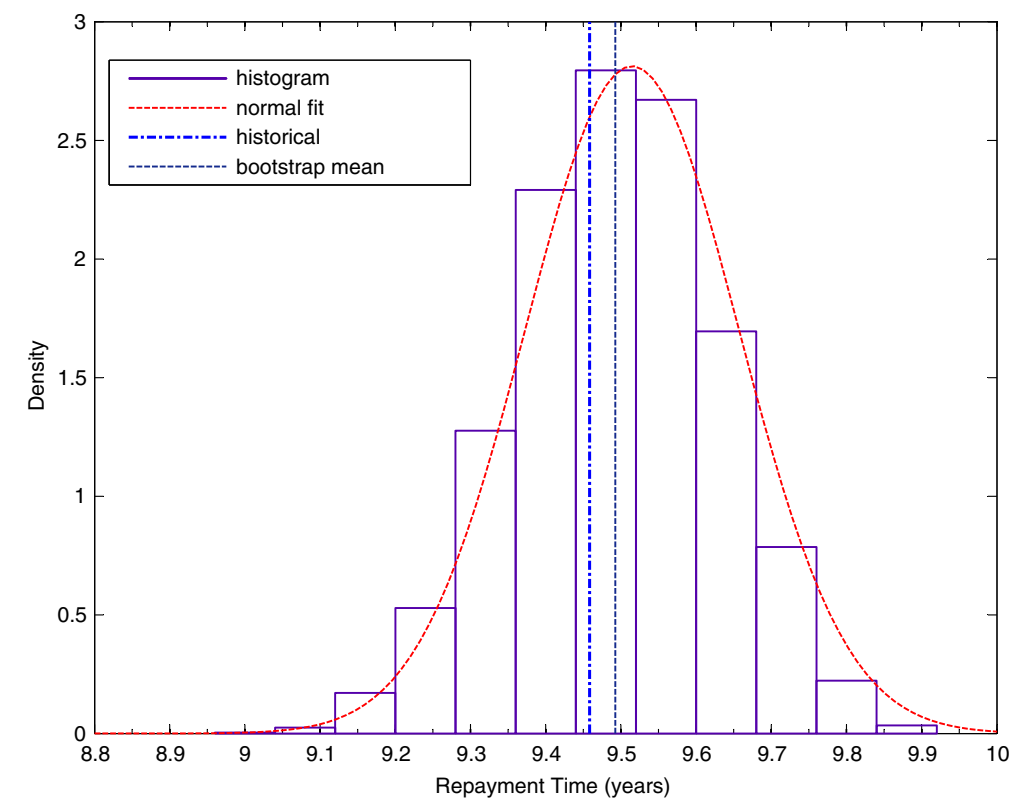

Figure 5 Histogram of repayment times by bootstrap analysis, capacity of $10 \mathrm{MW}$, FIT rate $\$ 0.44 / \mathrm{kWh}$, inverter efficiency $90 \%$, system efficiency $16 \%$, location London, ON rural area. Dashed line on the right denotes average repayment time obtained with bootstrap analysis and the dashed line on the left denotes average repayment time obtained with retrospective analysis.

sense, because in addition to modelling a completely different solar technology, (Powell et al. 2009) assume that the power was worth only the market price and not the much larger feed-in tariff price used here. According to Figure 5, the worst repayment time is 9.91 years and the best is 9.0 years. The difference between the two is less than 1 year, and the corresponding standard error of the simulated results is 0.16 years. These provide convincing evidence that FIT is an effective tool to eliminate the volume risk in financing solar PV plants. These results are helpful for those investing in solar PV plants, after which investors earn pure profits for approximately half of the contract life (10 years). Their investment are repaid after, at worst, 9.91 years. Second, the standard error of the repayment time is small. The repayment time falls in a narrow window, so even the worst case is not very much worse than the best case.

If, despite the evidence presented in section 'Data autocorrelation', there was a small auto-correlation in annual insolation, we could no longer use the naive bootstrap method presented here but would have to use the more sophisticated block bootstrap method (Hall et al. 1995). The result of such a study would likely show a positive auto-correlation would increase the probability of abnormally long repayment time while a negative autocorrelation would decrease this risk. This is most easily seen by consider the (unrealistic) limiting case of a $100 \%$ auto-correlated signal in which either insolation would always be very high (short repayment time) or very low (long repayment time). The current random setting favors more intermediate repayment times.

\section{Sensitivity analysis}

The methodology used here is broadly consistent with that used in other broadly similar studies such as (Kirby and Davison 2010; Drury et al. 2011; Davison et al. 2012); no exact comparison study to this has been published. We also test the robustness of these results via the following parameter sensitivity study.

As stated in section 'Introduction', solar PV projects are sensitive to government subsidies and economic policies. In this section, we investigate the repayment time under different schemes: varied interest rates and varied FIT rates. We evaluate the repayment time of solar PV plant at different interest rates and FIT rates respectively such that we could see how sensitive repayment times are with respect to certain economic inputs.

\section{Interest rate}

We vary interest rates from $5 \%$ to $10 \%$ with an $0.5 \%$ increment. We compare average repayment time of bootstrap analysis, retrospective analysis and constant insolation scenario. We plot average repayment time of these three scenarios under different interest rate settings below.

Figure 6 shows the repayment time calculated by constant insolation from section 'Solar PV financial basics', retrospective analysis and bootstrap analysis. The repayment times in all three cases increase as the interest rate 


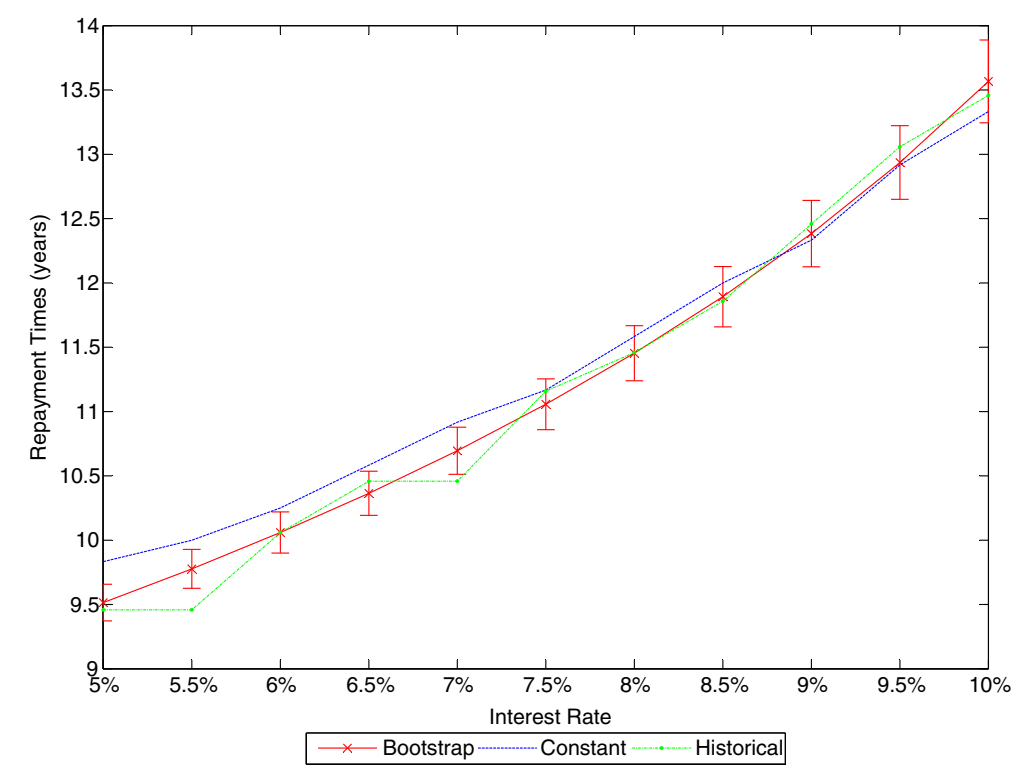

Figure 6 Repayment time, in years, capacity $10 \mathrm{MW}$, FIT rate $\$ 0.44 / \mathrm{kWh}$, inverter efficiency $90 \%$, system efficiency $16 \%$, location London, ON rural area. Solid line is obtained via bootstrap analysis, dashed line is obtained via constant insolation, and dashed line connected by circles is obtained via retrospective analysis. Bootstrap analysis resutls include \pm standard error width.

increases. The repayment time computed using bootstrap analysis fluctuates around the line obtained by using retrospective analysis. The repayment time obtained from the constant insolation assumption increases less rapidly than those curves obtained from bootstrap and retrospective analyses.

\section{FIT rates}

We vary FIT rates from $\$ 0.30 / k W h$ to $\$ 0.44 / k W h$ with an increment of $\$ 0.02 / \mathrm{kWh}$.

Figure 7 is the plot of repayment time under different FIT rates. The average value of repayment time decreases as the FIT rate increases, as does the variance.

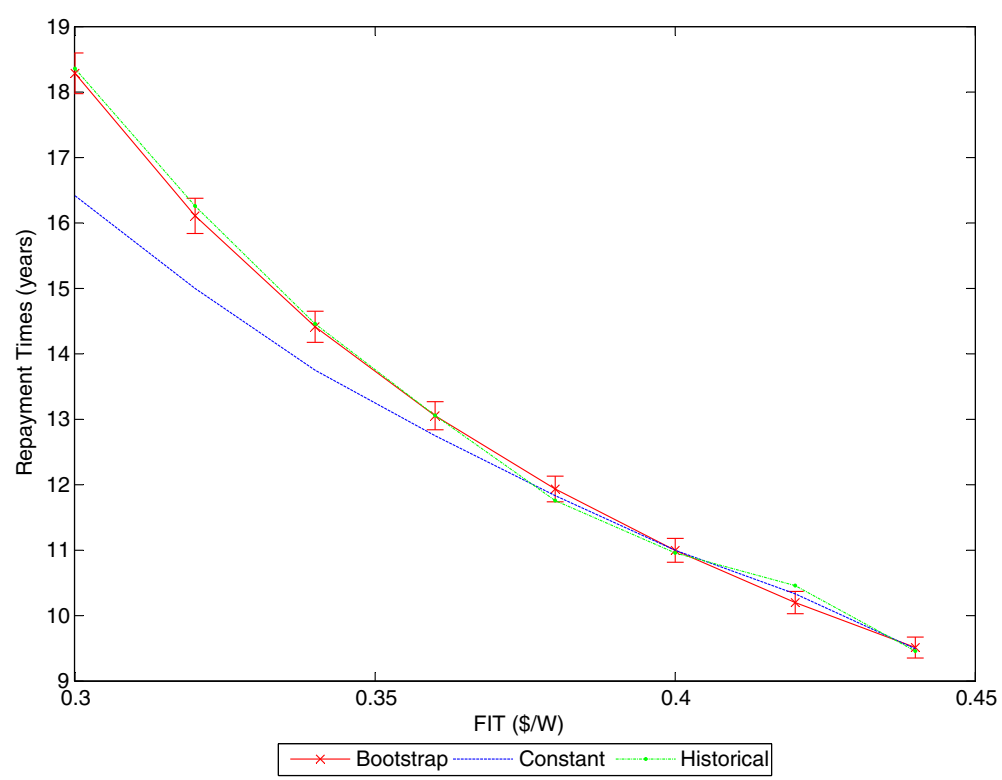

Figure 7 Repayment time varied by FIT rates, capacity $10 \mathrm{MW}$, interest rate $5 \%$, inverter efficiency $90 \%$, system efficiency $16 \%$, location London, ON rural area. Solid line is obtained with bootstrap analysis, dashed line via constant scenario and dashed line connected by dots is by retrospective analysis. Bootstrap analysis resutls include \pm standard error width. 
Moreover, comparing sensitivity to FIT rates and interest rates, suggests that repayment time is more sensitive to FIT rates than to the impact of interest rates.

\section{Cash flow at risk}

Cash Flow at Risk (CFaR) is another risk metric that can be used to quantify the risks associated with investment in solar PV plants. Cash Flow at Risk (CFaR) was first developed in 1999 by the RiskMetrics group to quantify, within some probability tolerance, the worst cash flow a company might experience over a given period (RiskMetrics Group 1999). A description of its use for non-financial firms or projects such as described in this paper is given in (Stein et al. 2001). The CFaR metric is in many ways analagous to the Value of Risk (VaR) metric used in financial risk measurement. The uses of VaR, and the way in which it may be calculated, is described in the book (Jorion 2000). The cash flow at risk measures the level below which the cash flows, normally of a non-financial firm, will not fall with some fixed probability in any given period. In mathematical terms,

$$
\operatorname{Prob}(\mathrm{E}(\mathrm{C})>\mathrm{CFaR})=\mathrm{p} \% \text {. }
$$

Here:

$\mathrm{E}(\mathrm{C})$ denotes firm/project's expected cashflow in a given duration, CFaR denotes cashflow at risk (in dollar amount), $\mathrm{p}$ is some fixed probability.

Using this measurement, we can investigate the level of the cash flows at some fixed probability and time duration.

We can also investigate the probability that the cash flows do not fall below 0 in any given year using CFaR measurement. For example, Figure 8 shows the distribution of cash flows for PV plant at 9.5 years. It shows that the probability of our model PV plant being debt free in 9.5 years is more than $50 \%$. This is, of course, fully consistent with the repayment times estimated in section 'Sensitivity analysis'. Figure 9 shows the $99 \%$ cash flow at risk for year 10 is estimated to be $(6.1294 \pm 5.3244) * 10^{5}$, a positive number. This shows that even under a worst case scenario, the plant load has been repaid with 10 years of FIT contract remaining.

This suggests the strong conclusion the average repayment times discussed in 2 are extremely robust to variation in insolation scenarios.

\section{Conclusions}

In this paper, we explored volume risk in a large scale solar PV plant under FIT based on a case study in Ontario,
Canada. We use two different risk metrics, repayment time and $\mathrm{CFaR}$, to investigate the impact of volume risk under FIT.

It can be shown that under the current FIT rate and other economic parameters, volume risk has little impact on financing solar PV plants. The repayment time of a solar PV farm is much more rapid than the 20 years over which the current FIT agreements guarantee pricing, even allowing for the occurrence of extreme events. Examined from another angle, the worst case cash flow at risk metric, fully confirm this result. Sensitivity analyses do not change this qualitative result. We conclude that the Ontario Canada FIT 2012 program was an effective tool to encourage investment in solar PV plants. We also find that repayment time is strongly sensitive to FIT rates. So FIT is a very efficient tool to impact/control the volume risk.

The method shown here can be applied to the engineering economic analysis of other solar power projects both in other areas of Ontario and outside that province. The idea of using a bootstrap approach to simulate on environmental data to financial outcomes, including the repayment time and $\mathrm{CFaR}$ metrics chosen here, is generally applicable. However, it works best in a FIT style financial environment in which electricity prices are constant. If this approach were to be used in a deregulated price environment, prices would also have to be simulated and their correlation with weather also considered. The quantitative results of this study suggest that Ontario's 2012 FIT levels would all be sufficient in sunnier areas of the world.

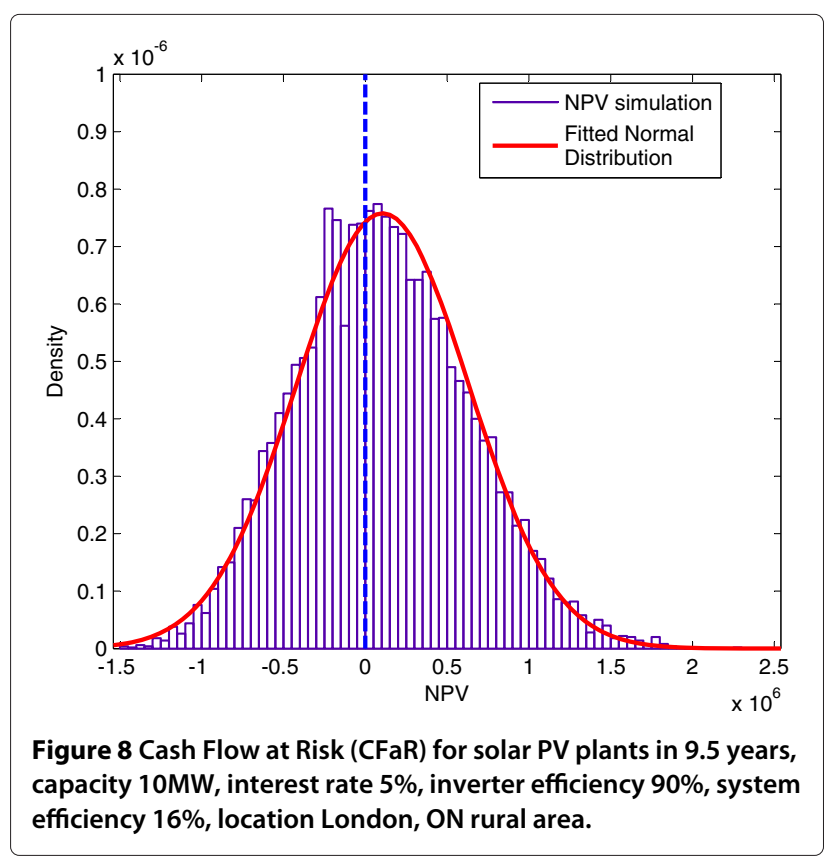




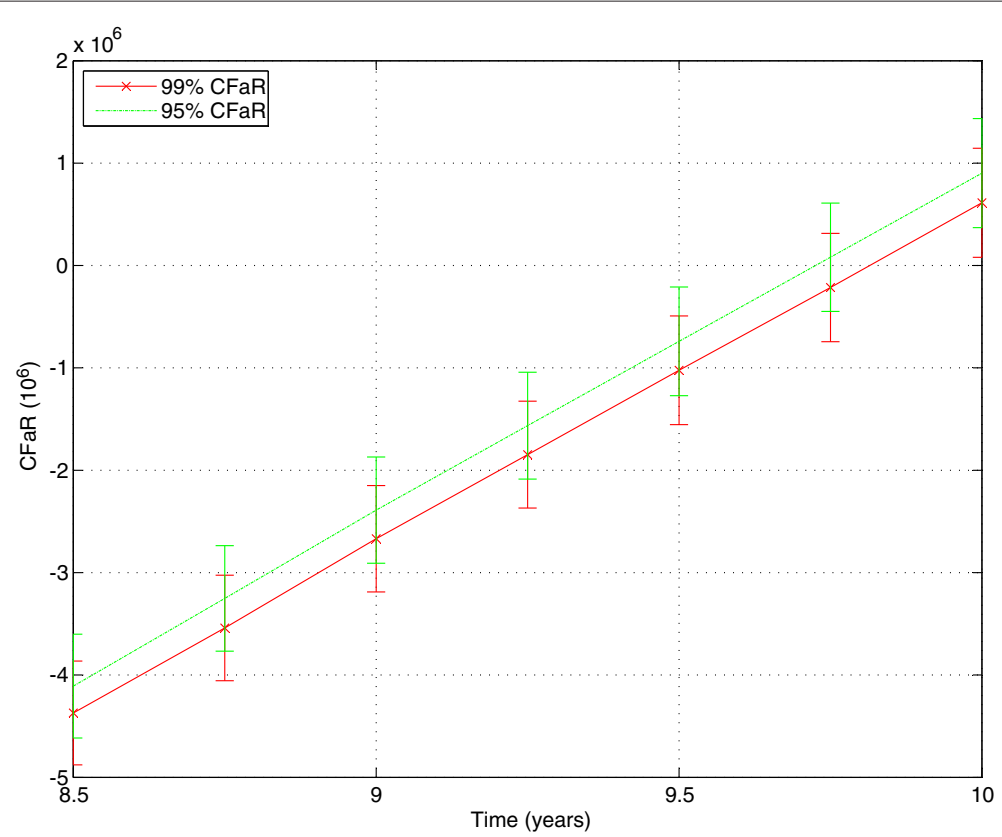

Figure $999 \%$ and $95 \%$ CFaR for solar PV plants in various years, from 8.5 to 10 years increased by 0.25 years, capacity $10 \mathrm{MW}$, interest rate $5 \%$, inverter efficiency $90 \%$, system efficiency $16 \%$, location rural area near London, ON.

\section{Appendix A}

\section{Cloud cover model}

When the Earth is 1 Astronomical Unit from the sun, the solar irradiance at the top of the earth's atmosphere on a unit area perpendicular to the beam is approximately $1367 \mathrm{~W} / \mathrm{m}^{2}$ (Lorenzo 2003). This number is called the solar constant.

In general, a reasonable fit to observed clear day global radiation data is given by (Kitchin 1987):

$$
G=G_{0} * \epsilon_{0} * 0.7^{A M^{0.678}}
$$

where $G_{0}$ is the solar constant, $\epsilon_{0}$ is the eccentricity correction factor and $A M$ is air mass. The air mass $(A M)$ is defined as the relative length of the direct-beam path through the atmosphere compared with a vertical path

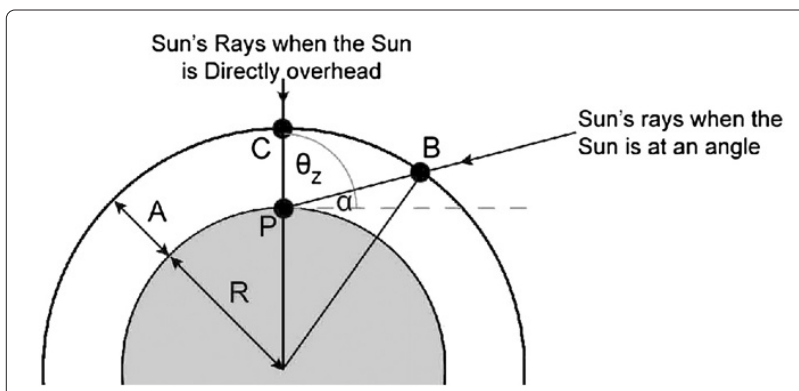

Figure $10 \mathrm{~PB}$ is the distance traveled through the atmosphere by the Sun's rays observed at point $\mathrm{P}$ when zenith angle is $\boldsymbol{\theta}_{\boldsymbol{s}}$. Source: figure 2.7 in (TACA 2012). directly from the top of the atmosphere to sea level. For an ideal homogeneous atmosphere, AM can be expressed in terms of the zenith angle $\theta_{z s}$, depicted in Figure 10:

$$
A M=\frac{1}{\cos \theta_{z s}}
$$

As a sun beam passes through the earth's atmosphere, the solar radiation is modified by the interaction with components such as water droplets. In atmospheric sciences,

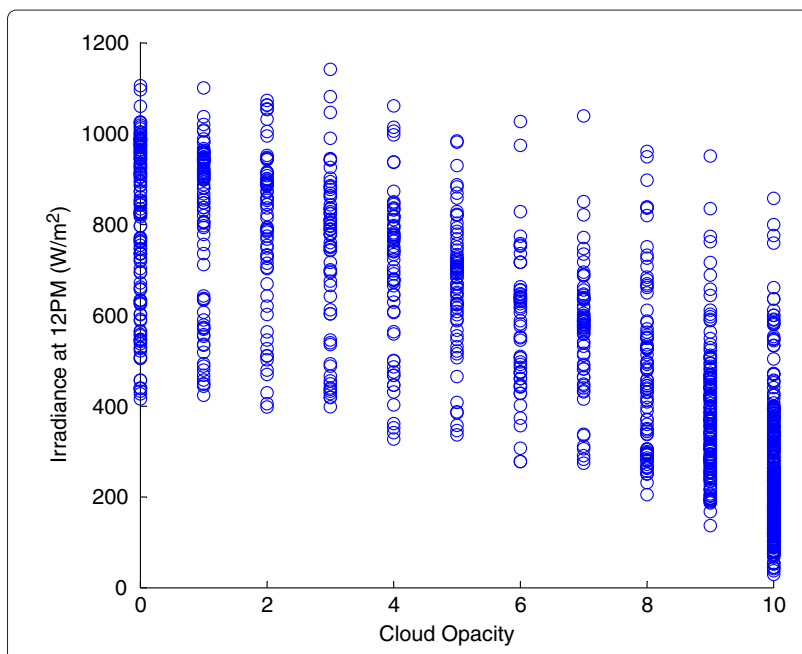

Figure 11 Daily global horizontal irradiance vs. cloud opacity at 12PM, year 2000 to 2004, data courtesy of Environment Canada. 
optical depth is a measure of the proportion of radiation absorbed or scattered along a path through a partially transparent medium (See Figure 10 for a conceptual illustration). The insolation is thus defined by the following equation:

$$
I=I_{0} * \exp -A M * \tau
$$

where $\tau$ is optical depth, $I$ is observed intensity after a given path and $I_{0}$ is the intensity of radiation at the source.

Consider that we could abstract the main component interacting with sun beam to be cloud, we scale cloud cover data to serve as $\tau$ in above equation and substitute $G$ in equation (3) for $I_{0}$.

Thus, the model of capturing global radiation at the ground level is:

$$
I=G_{0} * \epsilon_{0} * 0.7^{A M^{0.678}} * \exp ^{-A M * \tau}
$$

where $G_{0}$ is the solar constant, $\epsilon_{0}$ is eccentricity correction factor, AM is air mass and $\tau$ is optical depth.

Historical cloud cover data are obtained through Environment of Canada. But Figure 11 shows that the correlation between solar radiation and cloud cover is small. One explanation is that optical depth relates to cloud type as well as cloud extent.

Apparently, radiation collected on a day when the cloud cover is $100 \%$, but made up of high white clouds is nowhere close to that collected on a similar day when the clouds were lower and dark. As a result, we dropped the idea of modelling cloud cover and instead, used insolation data directly.

\section{Competing interests}

The authors declared that they have no competing interest.

\section{Authors' contributions}

$\mathrm{BL}$ and MD explored volume risk in a large scale solar PV plant under FIT based on a case study in Ontario, Canada, used two different risk metrics to investigate the impact of volume risk under FIT. MD suggested the problem setup. BL carried out all computations and drafted the paper, which MD helped edit and polish. Both authors read and approved the final manuscript.

\section{Acknowledgements}

MD thanks the Canadian Natural Science and Engineering Research Council for research funding which enabled this project to be carried out.

\section{Author details}

${ }^{1}$ Department of Applied Mathematics, University of Western Ontario, London, ON N6A 5B7, Canada. ${ }^{2}$ Department of Applied Mathematics, Department of Statistical and Actuarial Science, Richard Ivey School of Business, University of Western Ontario, London, ON N6A 5B7, Canada.

Received: 31 August 2012 Accepted: 23 January 2013

Published: 4 March 2013

\section{References}

Azzopardi B, Emmott CJM, Urbina A, Krebs FC, Mutale J, Nelson J (2011)

Economic assessment of solar electricity production from organic-based photovoltaic modules in a domestic environment. Energy Environ Sci 4(10): $3741-3753$
Bellemare B (2003) What is a megawatt? http://www.utilipoint.com/2003/06/ what-is-a-megawatt/\#.TrXPH3KA-go. Accessed March 8, 2012

Borenstein S (2008) The market value and cost of solar photovoltaic electricity production. http://escholarship.org/uc/item/3ws6r3j4. Accessed March 11, 2012

Davison M, Gurtuna O, Masse C, Mills B (2012) Factors affecting the value of environmental predictions to the energy sector. Environ Syst Res 1: 4

Drury E, Denholm P, Margolis R (2011) The impact of different economic performance metrics on the perceived value of solar photovoltaics. Tech. rep., NREL, http://www.nrel.gov/docs/fy12osti/52197.pdf. Accessed March 11,2012

Efron B, Tibshirani R (1994) An Introduction to the Bootstrap. Chapman \& Hall

Environment Canada (2012) Canadian Weather Energy and Engineering Data Sets (cweeds). ftp://arcdm20.tor.ec.gc.ca/pub/dist/climate/CWEEDS_2005/ ZIPPED\%20FILES/ENGLISH/. Accessed March 12, 2012

Germany (2000) Germany Renewable Energy Sources Act. http://www.windworks.org/FeedLaws/Germany/GermanEEG2000.pdf. Accessed October 10,2012

Hall P, Horowitz JL, Jing BY (1995) On blocking rules for the bootstrap with dependent data. Biometrika 82(3): 561-574

IESO (2012) Hourly Ontario Energy Price. http://www.ieso.ca/imoweb/ marketdata/marketSummary.asp. Accessed March 8, 2012

International Energy Agency (2009) National survey report of PV power applications in Canada 2008. http://198.103.48.154/fichier.php/codectec/ En/2009-128/2009-128_e.pdf. Accessed March 2012

Jorion P (2000) Value at risk: the new benchmark for managing financial risk, 2nd edn. McGraw-Hill

Kirby N, Davison M (2010) Using a spark-spread valuation to investigate the impact of corn-gasoline correlation on ethanol plant valuation. Energy Economics 32(6): 1221-1227

Kitchin C (1987) Stars, Nebulae and the Interstellar Medium: Observational Physics and Astrophysics. Taylor \& Francis

Lorenzo E (2003) Energy collected and delivered by PV modules. In: Luque A, Hegedus S (eds) Handbook of Photovoltaic Science and Engineering. John Wiley \& Sons, West Sussex, England, pp 905-970

Ontario Power Authority (2011) A Progress Report on Electricity Supply Third Quarter. http://www.powerauthority.on.ca/sites/default/files/OPA\%20\%20A\%20Progress\%20Report\%20on\%20Electricity\%20Supply\%20\%202011\%20Q3.pdf. Acessed March 12, 2012

Ontario Power Authority (2012) OPA FIT quick facts table for Solar PV. http://fit.powerauthority.on.ca/quick-facts-table-0. Accessed March 12 2012

Pappas C, Karakosta C, Marinakis V, Psarras J (2012) A comparison of electricity production technologies in terms of sustainable development. Energy Convers and Management 64: 626-632

Perez R, Letendre S, Herig C (2012) PV and grid reliability availability of PV power during capacity shortfalls. http://www.asrc.cestm.albany.edu/ perez/publications/PV\&20Power\%20outage/PV\&Grid\%20reliability-00.pdf. Accessed March 14, 2012

Powell C, Bender T, Lawryshyn Y (2009) A model to determine financial indicators for organic solar cells. Sol Energy 83(11): 1977-1984

PVResources (2012) Photovoltaic economics. http://www.pvresources.com/ Economics.aspx. Accessed March 12, 2012

Rehman S, Bader MA, Al-Moallem SA (2007) Cost of solar energy generated using PV panels. Renew and Sustainable Energy Rev 11(8): 1843-1857

REN21 (2010) Renewables 2010 Global Status Report. http://www.ren21.net/ Portals/97/documents/GSR/REN21_GSR_2010_full_revised\%20Sept2010. pdf. Accessed March 12, 2012

RiskMetrics Group (1999) Corporatemetrics Technical Document

Rowlands IH (2005) Solar PV electricity and market characteristics: two Canadian case-studies. Renew Energy 30(6): 815-834

Sidira KD, Koukios GE (2005) The effect of payback time on solar hot water systems diffusion: the case of Greece. Energy Convers and Management 46(2): 269-280

Solar Server (2010) Solar electricity: Grid-connected photovoltaic systems. http://www.solarserver.com/knowledge/basic-knowledge/gridconnected-photovoltaic-systems.html. Accessed March 11, 2012

Stein JC, Usher SE, LaGattuta D, Youngen J (2001) A comparables approach to measuring cashflow-at-risk for non-financial firms. J Corporate Finance 13(4): 100-109 
TACA (2012) Part 2: Solar energy reaching the Earths surface. http://www itacanet.org/the-sun-as-a-source-of-energy/part-2-solar-energyreaching-the-earths-surface/. Accessed March 8, 2012

US Treasury (2012) Clean Renewable Energy Bond Rates. https://www. treasurydirect.gov/GA-SL/SLGS/selectCREBDate.htm. Accessed March 12 2012

Weersink A, Deaton BJ, Bryan J, Meilke K (2011) Farmland prices. http://www. uoguelph.ca/catprn/PDF-TPB/TPB-11-01-Weersink-Deaton-Bryan-Meilke. pdf. Accessed March 16, 2012

White JA, Case KE, Pratt DB (2010) Principles of Engineering Economic Analysis, 5 th edn. Wiley, Hoboken, NJ

doi:10.1186/2193-2697-2-5

Cite this article as: Lu and Davison: Analyzing the impact of environmental variables on the repayment time for solar farms under feed-in tariff. Environmental Systems Research 2013 2:5.

\section{Submit your manuscript to a SpringerOpen ${ }^{\circ}$ journal and benefit from:}

- Convenient online submission

- Rigorous peer review

- Immediate publication on acceptance

- Open access: articles freely available online

- High visibility within the field

- Retaining the copyright to your article 